\title{
Entrepreneurial Possibilities in Graphic Arts and Design Education: A Survey on Printing Technology in Akure, Ondo State, Nigeria
}

\author{
Femi Kayode 1
}

\author{
${ }^{1}$ Department of Industrial Design, Federal University of Technology, P.M.B. 704 Akure, Ondo State, Nigeria
}

\begin{abstract}
Introduction
The experiential knowledge graphic arts and design education embrace are many and technologically complex, but it is timely to place a welcome emphasis on the entrepreneurial possibilities it stands to offer. One possibility is the graphic art technology which is often referred to as printing, publishing and packaging industry. A mounting pressure has emerged, according to Perry (2005) that is affecting the total package of education and the economic development of a nation. Acquisition of self-reliant skills and competencies should beget the eventual profile of any education goal. In the words of Akhuemonkhan (2005) and Oyetunji (2006) without vision a nation perishes. This presupposes that without entrepreneurship, economies perish. As successive governments in Nigeria are licensing private and public higher institutions for operations, the need for sustainable education continues to be of rapidly increasing economic and socio-economic worries. The specific objective of learning outcome should be such that school leavers in a given country are empowered to apply acquired skills and competences productively to fend for life expectancies always at leaving school. The concept of 'sustainability' of livelihood is an essential ballgame noted not only with rising concern but also as a matter of life and death. There is an urgent need to address some harsh realities in the planning, organization and administration of the Nigerian educational curriculum which hitherto has been indirectly responsible for the ailment of the national economy. This issue is global and more relevant to anyone involved in developing or delivering art and design curricular in schools (Hickman, 2005).
\end{abstract}

The clamour of the masses for the inculcation of economically assuring coursework contents in school curriculum, which prepares graduates for entrepreneurship is significantly increasing at every passing year. Hickman argues the need to totally reconceptualise the art and design curriculum. This is not unconnected with the pitiful plight of young, able-bodied school graduates who are bedeviled by 'idleness' and 'nothingness'. The concept of nothingness refers to a state of ridiculously inadequate survival means or the state of abject poverty caused by prolonged unemployment to many. The situation has been proven to defy the academic certification victims who sought admissions into higher institutions to pursue disciplines that are not enterprising enough for self-reliance but only civil service occupations. Rather, the situation requires a re-orientation of career pursuit away from the mindset of employee to employer. Skill acquisition from school and the private practice of such skills is considered as 'anti-poverty vaccine' for one reason that the government of this country has constantly reiterated her constraints to absorb all graduate citizens into its civil service employment. This decisive economic measure of government is expedient because the truth is such that the days of economic buoyancy and selective atmosphere for employment opportunities as well as ostentatious living are bygone era. Vividly, the unemployment pattern is rapidly devastating; many more youths are not only unemployed, they are 'unemployable'.

The challenge of socio-economic realities seeks to have growing agitation and strong contemplation for quality and marketability of the courses studied at school as part of the most significant educational issues. Ideally, schools should dish out practicable skills that are relevant to societal needs and which are enterprisingly possible for production outcomes. These are aspects of educational matters to be vigorously tackled at the faculty level. For the reason of promotion of indigenous technological industry as well as economic wellness of citizenry, the catalytic significance of entrepreneurial education with high

This article is published under the terms of the Creative Commons Attribution License 4.0

Author(s) retain the copyright of this article. Publication rights with Alkhaer Publications.

Published at: http://www.ijsciences.com/pub/issue/2015-12/

DOI: 10.18483/ijSci.893; Online ISSN: 2305-3925; Print ISSN: 2410-4477 
content of commercial initiatives cannot be overemphasized. To start with, marvelous opportunities should be made accessible to learners in tertiary institutions and other skill acquisition centres, in collaboration with the ministries of education to align with a particular skill that enhances entrepreneurial production system, control and sustenance.

Nevertheless, citizens of the world have not affirmed that government has provided all essential things they needed. Individuals have the bigger stake in this matter. In fairness, the past one or two decades have witnessed in Nigeria one entrepreneurship crusade or the other. The National Directorate of Employment (NDE), Small Scale Industries and Graduate Employment Programme (SSIGEP), Agricultural Sector for Employment Programme (ASEP) and the Directorate for Mass Employment, Social Mobilization and Economic Recovery (MAMSER) to mention just a few are government interventions. All are deeply rooted in technical and vocational education. However, the call for entrepreneurial education is not new but never before has it been so important than now when the work mentality of Nigerian, with reference to the perverted economy currently being experienced continues to be redirected towards self-reliance. This is opposed to the white-collar job mentality of the sixties, seventies and even the eighties occasioned by the oil boom.

The recent perpetual joblessness and the sudden loss of job sagacity are no more happenstance nor are they mere coincidence; they are realities of our time and are fast becoming epidemics that spread sporadically. There appears no appropriate time in our ongoing educational journey than now to train and produce thinkers who would widen the social and economic horizons of the Nigerian nation.

The background: Employment history in Nigeria Employment is only one area of life in which opportunities may increase or decrease (Adediji, 2010). Certainly, employment opportunities are declining in Nigeria due to dwindling economy, which is spelling bleakness to the future of the nation at large. A historical recollection of employment in this country has to do with the issue of education while that of unemployment is not unconnected with lack of vision on the part of leaders and managers of economic resources. Kayode (2004) remarks that youth unemployment in Nigeria has no definite period traceable to its inception but it can be recollected that there were very few schools producing literate youths that were fit and employable into the government service in the thirties and forties.

This period however also witnessed a few higher schools in Nigeria, such as Yaba Technical College (now Yaba College of Technology), Nigerian College of Art and Science, Zaria (now Ahmadu Bello University) and the University College, Ibadan (now University of Ibadan). But most of the few graduates available then were produced from institutions abroad. However, the standard four and six certificate holders were given employment in government establishments up till around the independence (1960) when there were needs to review the educational policy. This occurred over the years and many youths aspired to have higher education. Since the educational system changed during and after the independence, there has been policy upon policy, which culminated into the production of the modern three graduated, S.75, and the school certificate holders along with the few graduates. In this period also, more schools and higher institutions of learning sprang up to train manpower for government as a major employer of labour to employ.

In the early days of employment history, Nigerian graduates used to be assured of where to work for a living immediately at the point of passing out of the university.

Unfortunately the good old days seem to have gone forever, when employers of labour lobbied, scrambled and used enticing welfare stratagems to search for university graduates. The graduates on their own part selected jobs that have the most comparative advantage over the others in terms of special offers, incentives and conditional negotiations. Granted, employment is a springboard and a feeder source for other areas of human endeavours like education, healthcare, and other lifetime expectancies which also includes the breadwinning obligations, serving on the staff of another is otherwise economic stray jacket and insolvency.

Lest we forget, from the experience of our potentialities in this country, the oil resource pampered and blindfolded us to dumbfounding and drifted us away from a stable economy that we destined for ourselves through the mustering of the export of agricultural resources such as cocoa, groundnut, rubber, cotton and so on. Consequently we directly depended on the employment of government for a share of the "national cake". Should not the oil boom actually snowball us into the realm of "handwork education, 'producership' status and arouse in us an aggressive appetite and investment for the establishment of small and medium scale entrepreneurship in this country? Momoh (1985) has this to say, "if the increase in prices of oil in 1973 gave us more money than we could spend, it is obvious, looking back, that we did not prove able to foresee the disaster we are in now", pp8. What disaster? Folorunsho (2004) provides an insight to the answer, it says: Nigeria, the giant of African country in the sun, was so much in a hurry to catch up with the developed world. Hence in our bid to make haste 
so quickly, some fundamental screws were left loose in our planning wheel thereby causing intermittent dislocations, which has left the economy with a single income (relying solely on oil) and almost comatose forty years after the first steps were taken, pp76.

In short, the burden of over dependence on petroleum as a single resource is abundantly reflecting on the non-entrepreneurial lifestyles of those who crave to be employed by government.

This dismay is apparent in the form of physical hardships and poverty that are biting the citizenry with the teeth of granite today. But at the level of realities the intervention of pragmatic approach to a rounded education is solicited. It has therefore been realized that literacy education without specific enterprising skill is dumb and is as good as "anointing" which is wasted without the application of "wisdom". The position of John Ruskin cited in Standfield (1976) in this regard is thrilling, he says "life without industry is guilt, industry without art is brutality, (pp76). For this reason, it also becomes pertinent to refer to the visions in Olabode (2011), which envisage a practically coherent educational curriculum for Nigeria that will transmit more of practical knowledge and encourage business production methods right from school.

\section{Objectives of the study}

1. highlight the demographic characteristics of the printers in Akure;

2 investigate the relationship between the printers and their clients;

3. examine the printers' opportunity to raise capital for business; and

4. assess the professional proficiency of the printers.

Research questions

In the course of the research, the following research questions become pertinent in guiding the work:

1. What are the demographic characteristics of the printers in Akure?

2. How cordial is the relationship between the printers and their clients?

3. What methods are there for printers to raise capital for their business?

4. Are the printers professionally good to sustain the printing business?

\section{Review of related literature \\ Conceptual Issues in Education and Entrepreneurship}

Part of the problems with the issue of education generally is the definition of its concept. Education appears to be open to different interpretations and misconceptions. This is not unconnected with inadequate conceptual knowledge of the subject. Though it is of the essence, Kayode (2005) remarks that education transcends the mere ability to read and write. Rather, it permeates all the facets of human endeavours and developments to connote an allround development of an individual. Perceiving education as the same thing as schooling or ability to speak Queen's English underscores the adequacies of the concept and the perceived roles of education. Likewise, it is vague to see education as the feat of acquiring multiple academic certificates. Each of these notwithstanding is seen as integral to education, which in itself is not complete without the attainment of these factors. An educated person should be able to understand the complexities and diversities in the fundamental character of the society and be able to adapt to the emerging realities of societal norms and the way of life of fellow citizens. In this concept we understand education as a phenomenon that offers opportunities for the all round development of an individual.

Opportunities surrounding the framework and diversities of education are supposed to be rich, as we know them for a number of good reasons that education is business and it is industry. For this reason also, the notion of business education for learners in the different levels of schooling cannot be taken for granted. It provides a lucid conceptual picture of the importance of entrepreneurial education to the economy and the society at large. An entrepreneur, according to Ibidunni (2010), Berry and Wilson (2004) is a person who identifies business opportunities and organizes the required resources to initiate successful business activity. In Olabode (2011) an entrepreneur is defined as "an individual who either undertakes the responsibility of making innovations in the economy, (that is, introduce new goods, new methods of production or distribution, opening a new market, developing a new source of supply of raw materials) or carries out a new organization of any industry".

\section{Methodology}

The study used questionnaires to survey the opinion of respondents. Correlation analysis of Statistics was used in the interpretation of data. This is a set of statistical tool used to show relationship between variables and summarizing the numerical data. The data collected from the survey were assembled, collated, analyzed, related and classified as appropriate in groups according to respondents' answers as it relates to various objectives using frequency distribution, percentile and mean score. These were used to analyze the background information to the study as well.

The sample correlation coefficient, denoted $r$, is computed as follows:

$r=\operatorname{Cov} X, \mathbf{Y}$

$\operatorname{Var} X \operatorname{Var} Y$

Where $\operatorname{Cov} X, Y$ is the covariance of $\mathrm{X}$ and $\mathrm{Y}$, and $\operatorname{Var} X$ and $\operatorname{Var} Y$ are the sample variances of $X$ and 


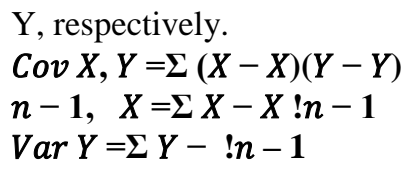

\section{Describe parameters and set up appropriate} hypotheses:

Parameter: $\boldsymbol{\rho}$ is the population correlation coefficient between variable $\mathrm{X}$ and variable $\mathrm{Y}$ H0: $\rho=0$ (no linear association) Ha: $\rho \neq 0$ (linear association)

2. The test statistic follows $t$ distribution with DF=n-2 degrees of freedom:

$$
1-r_{2} \quad \frac{n-2}{t=r}
$$

\section{Results and discussions}

Research question 1-4: Demographic characteristics (Gender, Work status, Working experience and Type of machines in use) of the printers in Akure?

There are printers among the clients and clients among the printers so a total of 389 questionnaires were administered to a mixed multitude of those who frequently patronize printers in their offices in Akure. From Table 1, it is stated that 280 questionnaires (72\%) were administered to the males while 109 questionnaires $(28 \%)$ were administered to the female counterpart. The responses of the respondents as to the demographic characteristics of the mixed respondents (printers and clients) were scored and summed up. The frequency percentages to each of them were computed. The results are presented in Tables 1-4.

Table 1. Gender distribution of commercial printers in Akure.

\begin{tabular}{ccc}
\hline Gender & Frequency & Percentage \\
\hline Male & 280 & 72.0 \\
Female & 109 & 28.0 \\
Total & $\mathbf{3 8 9}$ & $\mathbf{1 0 0 . 0}$ \\
\hline
\end{tabular}

Table 2: Work status distribution of the respondents

\begin{tabular}{ccc}
\hline Work status & Frequency & Percentage \\
\hline Client & 297 & 76.3 \\
Printer & 92 & 23.7 \\
Total & $\mathbf{3 8 9}$ & $\mathbf{1 0 0 . 0}$ \\
\hline
\end{tabular}

Table 3: Printing experience distribution of the respondents

\begin{tabular}{ccc}
\hline Working experience & Frequency & Percentage \\
\hline $1-10$ & 165 & 52.7 \\
$11-20$ & 86 & 27.5 \\
21 and above & 62 & 19.8 \\
Total & $\mathbf{3 1 3}$ & $\mathbf{1 0 0 . 0}$ \\
\hline
\end{tabular}

Table 4: Distribution of the types of printing press

\begin{tabular}{ccc}
\hline Type of printing press & Frequency & Percentage \\
\hline Letter press & 95 & 35.7
\end{tabular}




\begin{tabular}{lcc} 
Offset & 39 & 14.7 \\
Digital & 132 & 49.6 \\
Total & $\mathbf{2 6 6}$ & $\mathbf{1 0 0 . 0}$ \\
\hline
\end{tabular}

Table 5: Investigating the cordiality of work relationships between printers and their clients

\begin{tabular}{llccc}
\hline Item & \multicolumn{1}{c}{ Opinions/Parameters } & Mean & Std. Deviation & Rank \\
\hline 1. & Clients delight in patronizing printers in Akure. & 3.57 & 1.066 & 3 \\
2. & Printers give less prices when dealing with clients. & 3.28 & 1.195 & 4 \\
3. & The work relationship of printers and clients is cordial. & 3.75 & 1.004 & 2 \\
4. & The output of printers are always appreciated by clients. & 3.84 & 1.142 & 1 \\
\hline
\end{tabular}

Table 5 shows the mean and Standard deviation of the investigation made into the work relationship between printers in Akure and their clients. From the table, it is observed that respondents rated as most important that clients always appreciate the work done for them by the printers in Akure (item 4) with a mean score of 3.84 . This is more important to the public than any of the item opinions listed in Table 5. The Standard deviations indicates a divergence in the opinion of respondents in all the opinions rated by the respondents except in the rating of item 4 , signifying that respondents have different opinions regarding the printing press industries in Akure.

Table 6: Examination of printers' opportunity to raise capital for business

\begin{tabular}{lccc}
\hline Item Opinions/Parameters & Mean & Std. Deviation & Rank \\
\hline 5. Printing is not lucrative enough to attract loans or charity. & 2.99 & 1.118 & 2 \\
6. High cost of materials affects pricing of clients' jobs. & 3.72 & 1.084 & 1 \\
7. Every method of raising capital attracts high interests & 2.55 & 1.221 \\
8. Little education of printers hinders access to bank loans. & 2.93 & 1.239 & 4 \\
\hline
\end{tabular}

Table 6 shows that mean and Standard deviation of public opinion on printers' accessibility to the opportunity to raise capital for the continued operation of their printing business. From the table, it is observed that respondents rated as most important that high cost of printing materials is affecting printing job in Akure with a mean score of 3.72. This shows that the public is more concerned and worried about the high cost of printing materials than any other opinion or parameter on the list in Table 6. The Standard deviations indicates a divergence in the opinion of respondents in all the opinions rated by the respondents except in the rating of item 6 (High cost of materials affects pricing of clients' jobs), signifying that respondents have different opinions regarding printing industries in Akure.

Table 7: Assessment of the professional competence of printers in Akure

\begin{tabular}{llccc}
\hline Item & Opinions/Parameters & Mean & Std. Deviation & Rank \\
\hline 9. & Printers in Akure have up-to-date machines for work & 3.05 & 1.099 & 4 \\
10. $\quad$ Printers are trained and skillful to handle printing job. & 3.32 & 1.103 & 2 \\
11. Clients print jobs outside Akure because of poor finishing & 3.37 & 1.121 & 1 \\
12. Jobs printed in Akure can withstand those printed outside. & 3.11 & 1.079 \\
\hline
\end{tabular}

Table 7 shows the mean and Standard deviation of the public opinion on the professional competence of the printing industries in Akure. From the table, it is observed that poor execution and finishing of printed jobs are major factors that make customers take their work to other printers outside the town to accomplish. So they rated the printing of their jobs outside Akure as a result of poor finishing with a mean score of 3.37. This shows that printing jobs outside Akure is more important to the public than the rapid decline in the quick job-delivery habit of printing industries and other items in the table. The Standard deviations indicates a divergence in the opinion of respondents in all the opinions rated by the respondents except in the rating of item 11, thereby indicating that respondents have different opinions regarding printing industries in Akure.

\section{Empirical findings}

The study carried out a survey on entrepreneurial opportunities in graphic arts and design education 
with a focus on printing technology in Akure, Ondo State, Nigeria. It examined a number of opinions and parameters that eventually led to the research findings. A total of 389 respondents were contacted. There are more males than females that are actively involved in the printing enterprise. The old hands are the more experienced ones and are just about $20 \%$ of the total population of the 389 surveyed. Youths are fast taking over the business. More to this, the industry is growing and moving with the contemporary time and tide as printers are shifting massively towards the digital machine to produce fascinating printing jobs. Although there are a pocket of offset and letterpress printers, digital printing remains the hotspot and the in-thing.

\section{Conclusion}

A sample size of three hundred and ninety two was selected from the population using an appropriate sampling technique. Data were assembled using a structured questionnaire. Descriptive analysis, mean, standard deviation, frequencies, percentage and correlation method of analysis were used to analyze the data collected from the field.

The results of the analyzed data indicated that respondents

rated

Pictures of printing machines in use in Akure

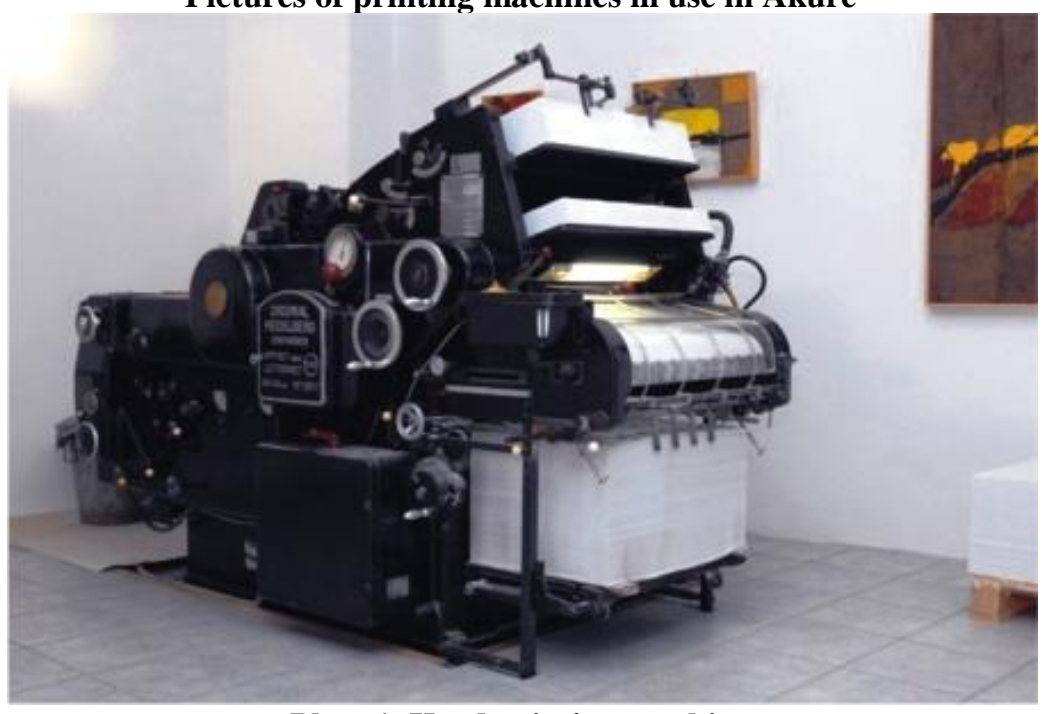

Plate 1. Kord printing machine

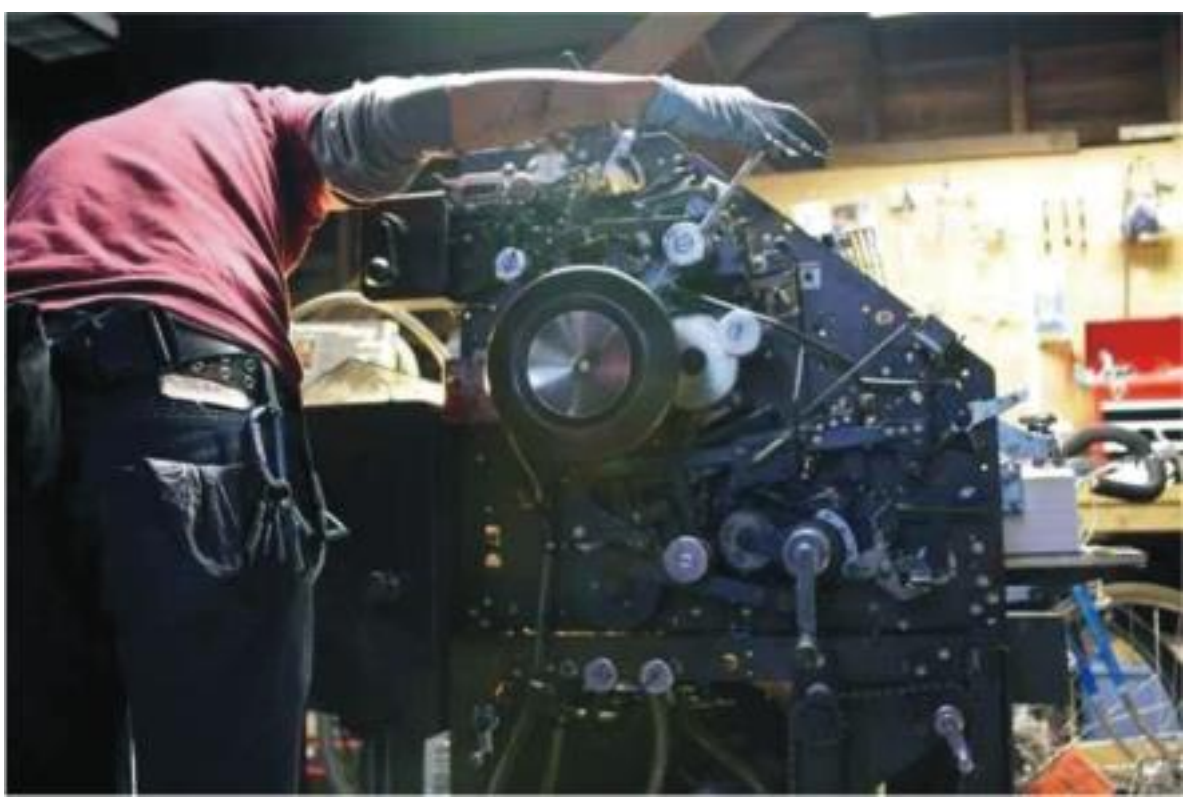

Plate 2: Printer working with the Kord printing machine. 


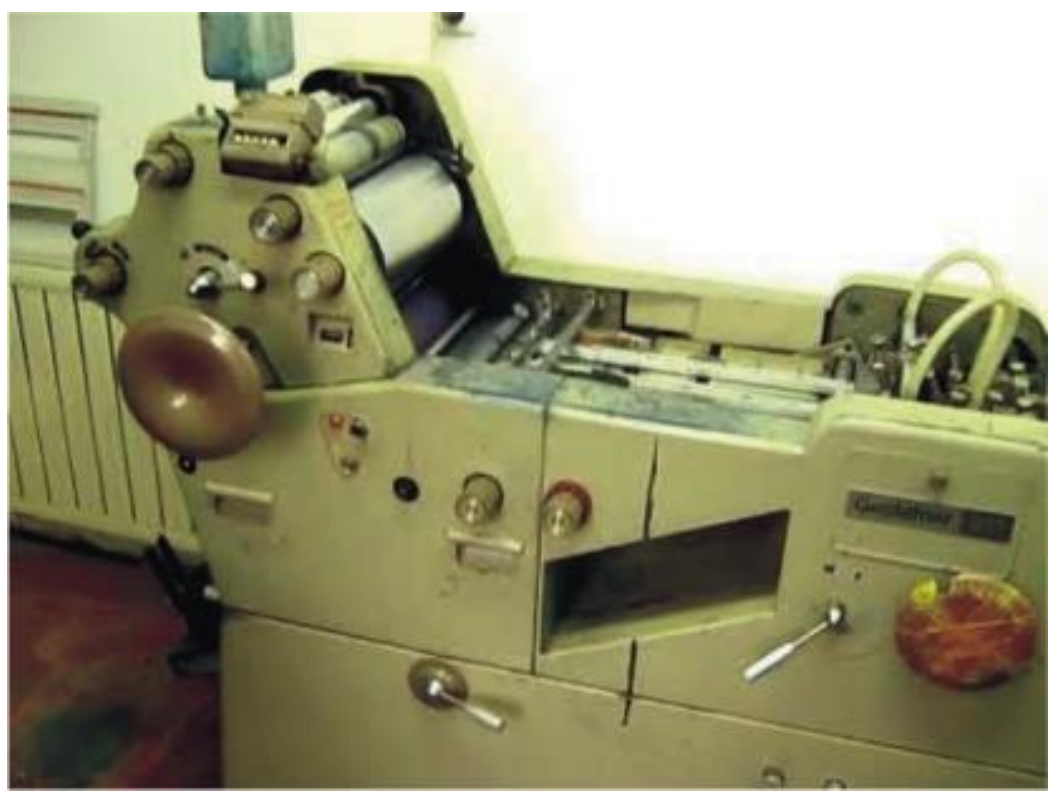

Plate 3: A GESTETNER 211 PRINTING MACHINE.

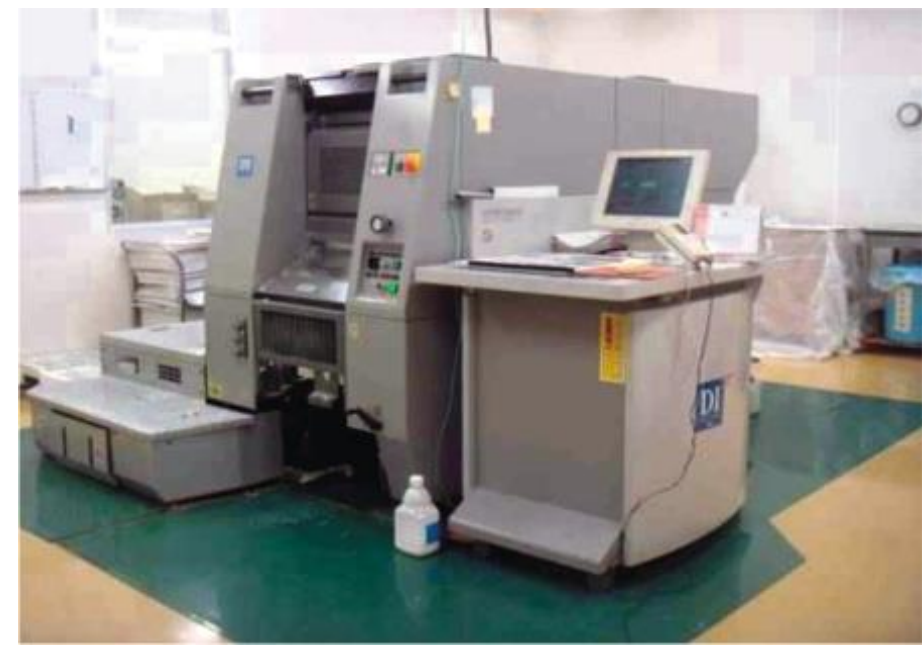

Plate 4: A direct image (computer-operated) printing machine.

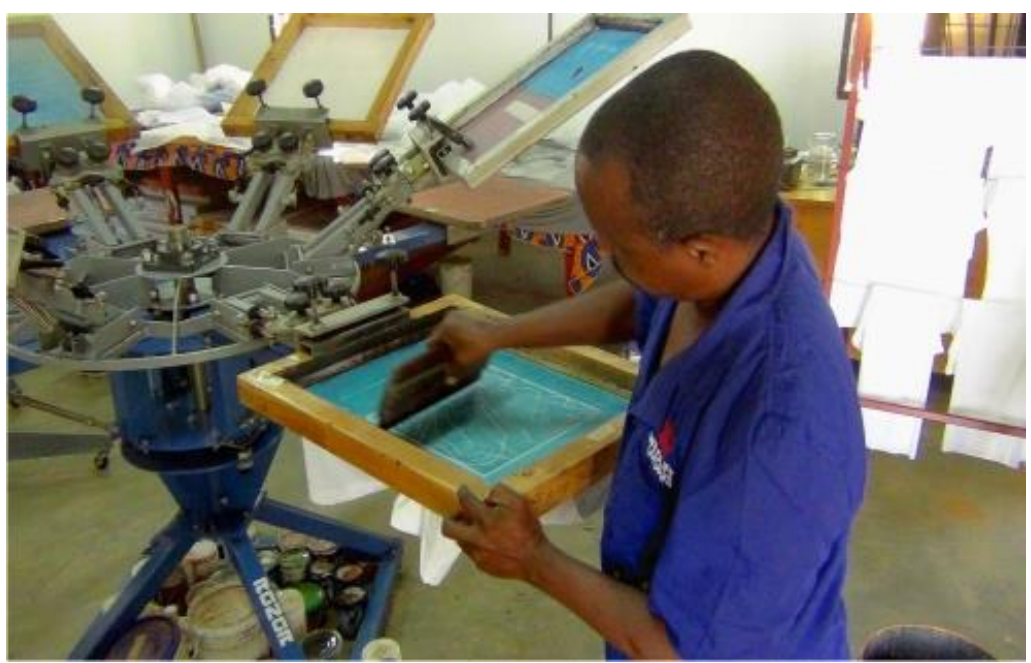

Plate 5: Screen printing machine. 


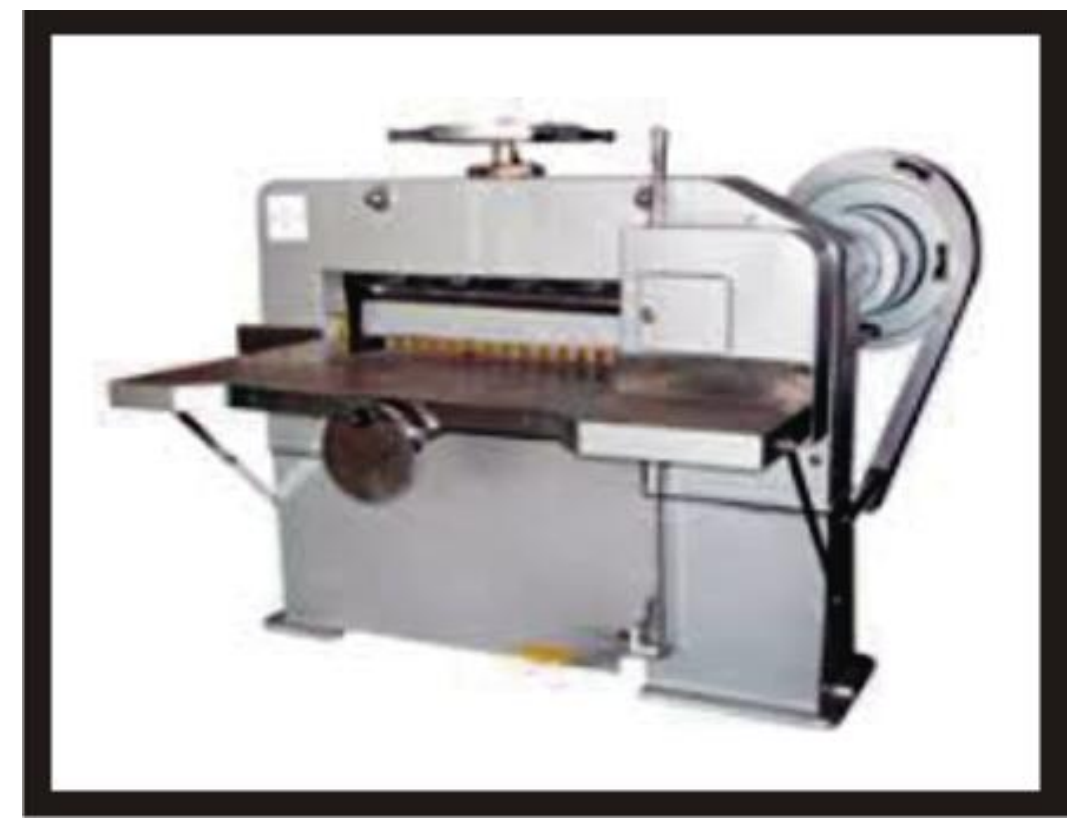

Plate 6: A guillotine - paper cutting machine.

\section{References}

1. Adediji, B. (2010). Mass poverty, environmental technology and leadership challenge. $3^{\text {rd }}$ Annual Lecture of the School of Environmental Technology, Federal university of Technology, Akure, $11^{\text {th }}$ November.

2. Akhuemonkhan, I., A. (2005). Modalities of teaching entrepreneurship in technical institution. Paper presented at the National Workshop on Capacity Building for Lecturers of Polytechnics and Monotechnics in Nigeria. Organized by EducationTrust Fund (ETF). August 22-26.

3. Berry, T. \& Wilson, D. (2004). On target: The Book on Marketing Plans. USA, Palo Alto Software, Inc.

4. Folorunsho, F. C. (2004). Developing Nigeria's economy through the visual arts. Journal of Arts and Ideas (JAI), 8, 7581.

5. Hickman, R. (2005). A short history of critical studies in art and design education. In Critical Studies in Art and Design Education, Richard Hickman (ed). United Kingdom, Intellect Books.

6. Ibidunni, O. S. (2010). Marketing research for excellence. Ota, Nigeria, Concept Publications.
7. Kayode, O. F. (2004). Screen printing vocation: A remedy to youth unemployment in Nigeria. Journal of Art and Ideas vol. 8, 13-17.

8. Momoh, T. (1985). The food. A publication of the Ministry of Information and Culture, Lagos. 7-10.

9. Olabode, F. T. (2011). Strategy for women empowerment to enhance self-reliance. Paper presented by the Mountain of Fire and Miracles Ministries for the Glorious Women Fellowship, Lagos, December 12-14.

10. Oyetunji, O. I. O. (2006). Development of entrepreneurship among the polytechnic students: A solution to graduate unemployment in Nigeria. Paper presented at the National Workshop on Capacity Building for Lecturers of Polytechnics and Monotechnics in Nigeria. Organized by Education Trust Fund (ETF). August 22-26.

11. Perry, L. (2005). Theoretical comments. In Critical Studies in Art and Design Education, Richard Hickman (ed). United Kingdom, Intellect Books.

12. Standfield, N. F. (1976). A handbook of the Art teaching in tropical schools, London. Evans Brothers publishers, 31 \& 224. 